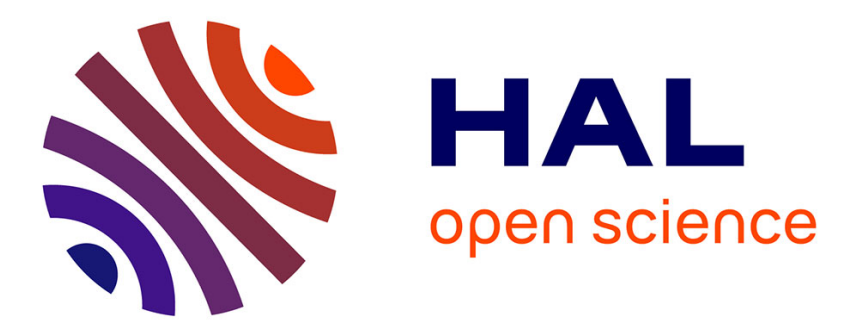

\title{
Prevalence and Prognostic Implications of Active Cytomegalovirus Infection in Patients with Acute Heart Failure
}

Julio Nuñez, Marifina Chilet, Juan Sanchis, Vicent Bodi, Eduardo Nuñez, Gema Miñana, Nuria Tormo, Maria A Clari, Mauricio Pellicer, Francisco J Chorro, et al.

\section{To cite this version:}

Julio Nuñez, Marifina Chilet, Juan Sanchis, Vicent Bodi, Eduardo Nuñez, et al.. Prevalence and Prognostic Implications of Active Cytomegalovirus Infection in Patients with Acute Heart Failure. Clinical Science, 2010, 119 (10), pp.443-452. 10.1042/CS20100162 . hal-00613581

\section{HAL Id: hal-00613581 https://hal.science/hal-00613581}

Submitted on 5 Aug 2011

HAL is a multi-disciplinary open access archive for the deposit and dissemination of scientific research documents, whether they are published or not. The documents may come from teaching and research institutions in France or abroad, or from public or private research centers.
L'archive ouverte pluridisciplinaire HAL, est destinée au dépôt et à la diffusion de documents scientifiques de niveau recherche, publiés ou non, émanant des établissements d'enseignement et de recherche français ou étrangers, des laboratoires publics ou privés. 


\title{
Prevalence and Prognostic Implications of Active Cytomegalovirus Infection in Patients with Acute Heart Failure
}

\begin{abstract}
Authors:
Julio Núñez $\mathrm{MD}, \mathrm{PhD}^{1}$, Marifina Chilet $\mathrm{MD}^{2}$, Juan Sanchis $\mathrm{MD}, \mathrm{PhD}^{1}$, Vicent Bodí MD, $\mathrm{PhD}^{1}$, Eduardo Núñez $\mathrm{MD}, \mathrm{MPH}^{1}$, Gema Miñana $\mathrm{MD}^{1}$, Nuria Tormo $\mathrm{MD}^{3}$, Maria A. Clari $\mathrm{MD}^{2}$, Mauricio Pellicer $\mathrm{MD}^{1}$, Francisco J. Chorro $\mathrm{MD}, \mathrm{PhD}^{1}$, Angel Llàcer $\mathrm{MD}, \mathrm{PhD}^{1}$ and David Navarro MD, $\mathrm{PhD}^{2,3}$

\footnotetext{
Affiliation:

${ }^{1}$ Cardiology Service, Hospital Clínico Universitario, INCLIVA, Universitat de Valencia, Spain

${ }^{2}$ Microbiology Service, Hospital Clínico Universitario, Valencia, Spain

${ }^{3}$ Department of Microbiology, Universitat de Valencia, School of Medicine Valencia, Spain
}

Key words: Acute Heart Failure. Cytomegalovirus Infection. Inflammation. Mortality. Risk stratrification.

Running headline: Cytomegalovirus Infection in Acute Heart Failure

\author{
Adress for correspondence: \\ Julio Núñez, M.D. \\ Servicio de Cardiología. Hospital Clínico Universitario \\ Avda. Blasco Ibáñez 17. 46010 Valencia-Spain \\ Tel: +34652856689 \\ Fax: +34963862658 \\ e-mail address: yulnunez@gmail.com
}

Word count: 3396 (excluding the reference list, tables and figure legends.)

Disclosures: No conflict of interests to declare 


\begin{abstract}
ABSTRACT

Objetives: Acute heart failure (AHF) causes significant morbidity and mortality. Recent studies have postulated that the expression of inflammatory mediators such as cytokines and chemokines plays an important role in the development and progression of heart failure. A proinflammatory state has been postulated as a key factor in triggering cytomegalovirus (CMV) reactivation. Therefore, we sought to determine the prevalence of active CMV infection in immunocompetent patients admitted for AHF and to quantify the association with the risk of the combined endpoint of death or AHF readmission.

Design: A total of 132 consecutive patients admitted for AHF were enrolled in the study. Plasma CMV DNAemia was assessed by real-time quantitative PCR. Cytokine measurements in plasma were performed by ELISA. Clinical data were evaluated by personnel blinded to CMV results. The independent association between active CMV infection and the endpoint was determined by Cox regression analysis.

Results: During a median follow-up of 120 days (IQR: 60-240), 23 (17.4\%) deaths, 34 (24.2\%) readmission for AHF and 45 (34.1\%) deaths/readmission for AHF were identified. Plasma CMV DNAemia occurred in $11(8.3 \%)$ patients, albeit at a low level $(<100$ copies $/ \mathrm{mL})$. The cumulative rate of the composite endpoint was higher in patients with CMV DNAemia $(81.8 \%$ vs. $29.8 \%, \mathrm{p}<0.001)$. After adjusting for established risk factors, the occurrence of CMV DNAemia was strongly associated with the clinical end-point $(\mathrm{HR}=4.39,95 \% \mathrm{CI}: 2.02-9.52$; $\mathrm{p}<0.001)$.
\end{abstract}

Conclusions: Active CMV infection occurs, though uncommonly, in patients with AHF, and may be a marker of disease severity. 


\section{INTRODUCTION}

Despite recent therapeutic innovations, advanced heart failure (HF) remains a serious medical condition with morbidity and mortality rates comparable or even higher than that for most malignancies [1]. Several studies support the involvement of inflammatory pathways in triggering the initiation and favoring the progression of HF [2-4]. In this context, proinflammatory cytokines, such as tumor necrosis factor- $\alpha$ (TNF- $\alpha$ ) and interleukin-6 (IL-6) appear to have detrimental effects on cardiac function [2-4]; Nevertheless, the prognostic implication of the inflammatory responses in HF remains unclear. Recently, some authors have highlighted the role of hyperinflammatory states in promoting cytomegalovirus (CMV) reactivation [5]. CMV infection causes significant morbidity and mortality in immunocompromised patients, not only as a result of virus cytopathogenicity ("direct effects"), but also by virtue of its immunomodulatory properties ("indirect effects") [6]. The latter effects may account for the reported association between CMV infection and chronic allograft rejection in solid organ transplant recipients, particularly transplant-related vasculopathy, whose histopathology remarkably resembles that of atherosclerosis [7]. In line with this, a role for CMV in the pathogenesis of cardiovascular diseases has been postulated [7,8].

Data obtained in the murine cytomegalovirus model indicate that a proinflammatory state is a critical factor in promoting CMV reactivation [5]. In this mechanistic model, TNF- $\alpha$, a cytokine known to directly stimulate immediate early (IE) CMV gene expression in vitro [9], may play a pivotal role [10]. In fact, intraperitoneal administration of well-known inflammatory mediators in HF, such as lipopolysaccharide (LPS) and TNF- $\alpha$, were capable of reactivating CMV from latency in lungs of previously healthy mice [5]. We thus hypothesized that active CMV infection was likely to occur in acute heart failure (AHF) patients and that it may have prognostic implications. In the current study, we sought to determine in a cohort of patients with AHF: 1) the prevalence of CMV infection; 2) whether active CMV infection was associated with an increased risk for the composite endpoint of short-term all-cause mortality or readmission for AHF and; 3) whether those patients with an active CMV infection displayed higher rates of hospitalized-day per weeks of follow-up. 


\section{METHODS}

\section{Study group}

We prospectively studied a cohort of 138 patients consecutively admitted to the cardiology department of Hospital Clínico Universitario de Valencia from $1^{\text {st }}$ November 2008 to $19^{\text {th }}$ May 2009 with the diagnosis of AHF. Diagnosis of AHF was defined as the rapid onset of symptoms and signs secondary to abnormal cardiac function and the presence of objective evidence of structural or functional abnormality of heart at rest (cardiomegaly, third heart sound, cardiac murmur, abnormality of the echocardiogram or raised natriuretic peptide), following current guidelines [11] and established by a trained cardiologist. Exclusion criteria were known or suspected infections, any systemic inflammatory disease different from heart failure, immunodeficiency, end-stage renal disease undergoing dialysis, cancer, blood transfusion within 30 days, and the need for mechanical ventilation before blood sampling. One hundred thirty eight patients were initially selected, but 6 patients were later excluded because of death before blood sampling $(n=2)$, a final diagnosis of acute coronary syndrome $(n=2)$, pneumonia $(n=1)$ and cancer $(\mathrm{n}=1)$, leaving the study sample in 132. Demographic information, medical history, vital signs, 12-leads electrocardiogram, laboratory data and drug utilization were routinely determined in emergency department and throughout the hospital course following pre-established registry questionnaires. Left ventricular ejection fraction (LVEF) was assessed with two-dimensional echocardiography in all patients during index hospitalization (Agilent Sonos 5500-Phillips).

All patients received intravenous treatment with furosemide at least during the first 48 hours of admission. Treatment with angiotensin converting enzyme inhibitors (ACEI), angiotensin receptor blockers (ARB), betablockers, aldosterone antagonist, anticoagulants and other therapeutic strategies was individualized following established guidelines [11].

Patients' follow-up was censored if death occurred or by having undergone cardiac transplantation or cardiac valve replacement surgery. The composite of all-cause mortality and readmission for AHF was selected as the main clinical endpoint. As secondary endpoint, the cumulative incidence rate of hospitalized-day per week of follow-up was compared between those with and without CMV DNAemia. This study was approved by an institutional review committee and patients gave written informed consent.

\section{Assays}

Following an overnight fasting, venous blood samples were drawn from the antecubital vein between 8:30 h and 9:30 h with patients in resting supine position for at least $15 \mathrm{~min}$ prior to sampling. IgG and IgM antibodies against CMV were detected by means of a commercial immunoassay (Architect CMV IgG assay, Abbott Diagnostics, Des Plaines, IL, USA). CMV DNA load was measured by real-time PCR with the Abbott CMV PCR kit (produced by Qiagen GmbH, Hilden, Germany, for Abbott Diagnostics, Des Plaines, IL, USA), performed using the m2000RT system (Abbott Molecular) and following the manufacturer's instructions, as previously described [12]. DNA extractions (from $500 \mu \mathrm{l}$ of plasma) were performed using the Abbott mSample preparation system DNA kit on the m2000 SP instrument (Abbott Molecular). The reported limit of detection of the assay (95\% C.I.) is 25 CMV DNA copies/mL [12]. The assay is, however, able to reliably quantify lower CMV DNA loads (Navarro D, unpublished observation). Specimens with CMV DNA loads $<25$ copies $/ \mathrm{mL}$ were reassayed using a different 
aliquot and were regarded as positive if they yielded a reproducible CMV DNA load value. Measurements were performed by a technician completely blinded to patient diagnosis and evolution.

\section{Plasma cytokines analysis}

Plasma levels of TNF- $\alpha$, IL-6, interleukin-1beta (IL-1 $\beta$ ) and interleukin-10 (IL-10) were quantified by enzyme-linked immunosorbent assay (ELISA) using commercially available kits (eBioscience human IL-1 $\beta$, IL-6, TNF- $\alpha$ and IL-10 ELISA Ready-SET-Go!). The sensitivity claimed by the manufacturer for the different cytokine assays were: $3.0 \mathrm{pg} / \mathrm{mL}$ for TNF- $\alpha, 4.0$ $\mathrm{pg} / \mathrm{mL}$ for IL-1 $\beta, 2 \mathrm{pg} / \mathrm{mL}$ for IL-6, and $2.0 \mathrm{pg} / \mathrm{mL}$ for IL-10. High-sensitivity ELISAs were used for cytokines measurements in samples giving values below the detection limit in the respective low-sensitivity assay. The concordance between the values obtained in the low-sensitive assay (for those above the detection limit) and those in the high-sensitive assay approached $100 \%$.

\section{Statistical analysis}

Continuous variables were expressed as median (interquartile range). Discrete variables were presented as percentages. Baseline characteristics were compared among those patients with and without CMV DNAemia. Using standard cutpoints CMV DNAemia was also categorized by the presence of $>25$ copies $/ \mathrm{mL}, \leq 25$ copies $/ \mathrm{mL}$ or negative (undetectable CMV DNA) results. The composite of mortality/AHF rehospitalization rates was depicted among the CMV DNAemia status using the Kaplan-Meier method, and their differences tested by the Peto-Peto Prentice test. The independent association between CMV DNAemia categories and the main outcome was assessed with Cox regression analysis. Candidate covariates for the initial multivariable model included all variables listed in table 1 , including cytokines. Then, a reduced and parsimonious model was derived by using the Royston and Altman model-selection algorithm [13]. The final Cox model included the following covariates: previous admission for AHF, systolic blood pressure at admission $(\mathrm{mmHg})$, Charlson comorbidity index, serum sodium $(\mathrm{mEq} / \mathrm{L})$, serum NTpro brain natriuretic peptide (BNP) $(\mathrm{pg} / \mathrm{ml})$ and serum antigen carbohydrate 125 (CA125). The proportionality assumption for the hazard function over time was tested by means of the Schoenfeld residuals. The model's discriminative was assessed by the Harrell's C-statistic while its calibration tested by the Gronnesby and Borgan test [14]. For the secondary analysis, negative binomial regression was used to determine the incidence rate ratio (IRR) of patient's hospitalized-day per week of follow-up according to CMV DNAemia status. Independent predictors included in this model were: age, smoking status, last NYHA class measured under stable conditions, previous admission for AHF, valvular heart disease, anemia, lymphocyte relative count, CA125, uric acid, TNF- $\alpha$, left ventricular ejection fraction and treatment with furosemide, espironolactone, statins and treatment with inotropic drug support.

A 2-sided p-value of $<0.05$ was considered to be statistically significant for all analyses. All analyses were performed using STATA 11 (StataCorp. 2009. Stata Statistical Software: Release 11. College Station, TX: StataCorp LP). 


\section{RESULTS}

\section{Prevalence of active CMV infection}

One hundred and twenty nine patients $(97.7 \%)$ were CMV IgG-seropositive. A single analysis for the presence of CMV DNA in plasma was performed (median of 3 days -IQR 1-5 days- following admission). CMV DNA was detected in plasma from $11(8.3 \%)$ patients, 4 of whom had CMV DNAemia levels of $>25$ copies $/ \mathrm{mL}$ (median 43 copies $/ \mathrm{mL}$; range, 31 to 72 copies $/ \mathrm{mL}$ ). Lower CMV DNAemia levels (median 10 copies $/ \mathrm{mL}$; range, 6 to 12 copies $/ \mathrm{mL}$ ) were consistently detected in the remaining 7 patients. Six patients $(4.6 \%)$ tested positive for CMV IgMs, 2 of whom tested positive for CMV DNAemia. Time to sampling after admission did not differ significantly ( $\mathrm{p}=0.656$ ) between patients with or without CMV DNAemia.

\section{Characteristics of patients across CMV status}

The mean age of patients in the sample was $76 \pm 13$ years; 64 patients $(48.5 \%)$ were female, $70(53 \%)$ had been previously admitted for AHF and 78 (59.1\%) exhibited left ventricular ejection fraction $\geq 45 \%$. Table 1 shows the clinical characteristics of the study population according to the CMV DNAemia status. Patients with active CMV infection displayed more frequently $\mathrm{LVEF}<45 \%$, had lower median systolic and diastolic blood pressures, and exhibited a trend for a higher median NT-proBNP serum values. Interestingly, no differences were found in age, gender, cardiovascular risk factors, ethiology, presentation, comorbidity and treatment between groups.

\section{Inflammatory status and active CMV infection}

Plasma levels of several proinflammatory and immunoregulatory cytokines were measured in patients with (at the time of CMV DNA detection) and without active CMV infection. Patients exhibiting CMV DNAemia showed lower median IL-10 values and higher median TNF- $\alpha / \mathrm{IL}-10$ and TNF- $\alpha / \mathrm{IL}-6$ serum values (Table 1). These differences were particularly evident when patients were stratified on the basis of their CMV DNAemia load (none, $\leq$ and $>25$ copies $/ \mathrm{mL}$ ) (Figure 1 ).

\section{CMV infection and death/readmission for AHF}

During a median follow-up of 120 days (IQR: 60-240), 23 (17.4\%) deaths, 34 (24.2\%) readmissions for AHF and $45(34.1 \%)$ deaths/readmission for AHF were identified. The cumulative rates for death, readmissions for $\mathrm{AHF}$ and the composite endpoint were higher for patients with CMV DNAemia (45.5\% vs. $14.9 \%, 63.6 \%$ vs. $20.7 \%$ and $81.8 \%$ vs. $29.8 \%$, respectively; $\mathrm{p}<0.001$ for all comparisons) than for those not experiencing it, with tangible differences observed since the first days of follow-up for death and the composite endpoint of allcause mortality/readmission for AHF (Figure $2 a$ and $2 b$, respectively). Detailed medical history and evolution of 11 patients who exhibited CMV DNAemia are shown in Table 2.

Under a multivariate context, after adjusting for established prognostic factors and potential confounders, including previous admission for AHF, systolic blood pressure, Charlson comorbidity index, serum sodium, serum NT-proBNP and tumor marker antigen carbohydrate 125 (CA125), the occurrence of CMV DNAemia remained strongly associated with the endpoint $(\mathrm{HR}=4.39,95 \% \mathrm{CI}: 2.02-9.52 ; \mathrm{p}<0.001)$ (Table 3$)$. In a sensitivity analysis including in the final multivariate model TNF- $\alpha$, IL-6 and IL-10 values, independently of their p-value, CMV DNAemia remains associated with the main endpoint ( $\mathrm{HR}=4.84,95 \% \mathrm{CI}: 2.10-11.15 ; \mathrm{p}<0.001)$. 
In addition, a risk gradient was found according to the magnitude of the viral load. Thus, compared to patients with undetectable CMV DNAemia, patients with $>25$ copies $/ \mathrm{ml}$ showed a prohibitive adjusted increased risk of death or readmission (HR=13.6, CI 95\%: 3.98-46.58; $\mathrm{p}<0.001$ ) whereas patients with CMV DNAemia of $\leq 25$ copies $/ \mathrm{mL}$ showed and intermediate increased risk $(\mathrm{HR}=2.93$, CI 95\%: 1.11-7.71; $<<0.030)$ (Table 3). It is noteworthy to point out that all patients who displayed CMV DNAemia of $>25$ copies $/ \mathrm{mL}$ died within the first 100 days following index admission (one of them died during index admission and in the rest, death was preceded by a readmission for AHF) (Table 2).

Likewise, patients with detectable CMV-specific IgMs displayed an increased risk of the composite endpoint (Figure 3). This excess of risk attributable to the presence of CMV-specific IgMs remained strongly significant in multivariate analysis, including CMV DNAemia as a variable (HR: 6.91, CI 95\%: 1.95-24.5; $\mathrm{p}=0.003$ ). Since presence of DNAemia and CMV-specific IgMs yielded similar prognostic and biological meanings, collapsing them into one category, led us to identify a subgroup of subjects $(\mathrm{n}=15)$ with a very-high risk of death/rehospitalization for AHF (HR: 4.70, CI 95\%: 2.29-9.61; $<<0.001$ ).

Harrell's C-statistics of the multivariate models that included CMV DNAemia either as binary or three-level variable showed higher discriminative ability $(0.787$ and 0.789$)$ than the model without it (0.764). The Gronnesby and Borgan test of goodness-of-fit showed a good model's calibration $(\mathrm{p}=0.579)$.

\section{CMV and cumulative incidence hospitalized-day rates}

The presence of CMV DNAemia identified a subset of patients with a higher: a) median (IQR) length of stay during the index hospitalization [23 days (11) vs. 11 days $(10), \mathrm{p}<0.001]$, b) cumulative patient's hospitalized-day [42 days (24) vs. 15 days $(18), \mathrm{p}=0.001$ ] and patient's rates of hospitalized-day/per week of follow-up (1.07 vs. 0.78 days/week of follow-up, $p=0.031)$. Using negative binomial regression, the IRR calculated for the presence of CMV DNAemia was 1.99 , CI $95 \%$ CI: $1.04-3.82 ; \mathrm{p}=0.037$, association that remained significant and in the same direction after multivariate adjustment (IRR: $2.40,95 \%$ CI: $1.44-4.02 ; \mathrm{p}=0.001$ ). 


\section{DISCUSSION}

To the best our knowledge, this is the first study reporting that active CMV infection occurs in patients with AHF, and that in this clinical setting, appears to exert detrimental effect on prognosis.

It is now widely accepted that an activation of the immune system occurs in patients with chronic heart failure, leading to an inflammatory state that appears to be determinant in disease progression $[2-4,15]$. In this sense, serum levels of TNF- $\alpha$, IL-6 and soluble TNF-receptors I and II have been shown to correlate with disease stage and progression, and ultimately with a poorer prognosis in chronic and in AHF $[2-4,16,17]$. TNF- $\alpha$ has been shown to trigger CMV reactivation from latency at the cellular level [5]. In this context, active CMV infection has been shown to occur frequently in critically ill patients without canonical immunosuppression [18-20], especially in those with severe sepsis, a biological condition leading to CMV reactivation in the murine CMV model [5]. In this setting, CMV may perpetuate and aggravate the inflammatory state by virtue of its immunomodulatory properties [21,22]. This may account for the reported association between CMV infection and prolonged hospitalization, longer duration of mechanical ventilation and higher rates of nosocomial infections and overall mortality in this clinical setting [18-20].

On the basis of the above assumptions, we reasoned that active CMV infection was likely to occur in patients with HF, especially during an acute episode. Indeed, we found that CMV DNAemia occurred at a low level $(<100$ copies $/ \mathrm{mL})$ in $8.7 \%$ of cases. The above findings are reminiscent to those reported in critically ill patients without canonical immunosuppression experiencing an active CMV infection, in which a rapid expansion of CMV-specific functional $\mathrm{T}$ cells in response to CMV replication keeps systemic CMV load at a low level until complete resolution of the episode [23]. In addition, in our cohort, the occurrence of CMV DNAemia was independently associated with an increased risk of morbidity and mortality. This association was particularly evident when patients were stratified according to their level of CMV DNAemia, those displaying CMV DNAemia levels $>25$ copies $/ \mathrm{mL}$ being at the highest risk. In fact, the 4 patients with in the upper CMV DNAemia category died during the first 100 days following the index admission. In line with our findings, the magnitude of the CMV DNA load has been recently reported to be independently and quantitatively associated with prolonged hospitalization and death after adjusting for parameters indicative of severity such as APACHE II score and other potential confounders in a cohort of critically ill patients attended at different intensive care units [19].

Further, the presence of CMV-specific IgMs, a well-known marker of CMV reactivation in immunocompetent individuals harboring latent CMV [24], was independently associated to an increased risk of death/readmission for AHF. The possibility exists nevertheless that IgMs detected were not truly CMV specific [24].

Whether CMV is a direct cause of morbidity and mortality in patients with AHF or it is simply a surrogate marker for disease severity could not be elucidated in the current study. CMV may reactivate in AHF patients in the setting of a pro-inflammatory state. As an immunomodulatory agent, CMV may enhance inflammation which would result in further myocardial injury [4, 15, 25-27] or may even increase the risk of secondary infections [22], a well recognized precipitating factor for HF descompensation [11]. The fact that patients with active CMV infection exhibited an enhanced immunoinflammatory state (higher plasma TNF $\alpha$ - 
/IL-10 and IL-6/IL-10 ratios) when compared to those without active infection provides support to the plausibility of this hypothesis.

Our results, however, must be interpreted with caution: First, this is a preliminary observational study that includes a limited number of patients with AHF; second, despite the strength of the association, the low number of patients with active CMV infection precludes the inference of more precise estimates; third, as no sequential measurements were performed, peak CMV DNAemia values for some patients may have been missed, and finally, some patients might have been miscategorized due to the intrinsic interassay coefficient of variation of the qPCR used in this study (estimated to be within 20-30\% for low CMV DNA loads)

\section{CONCLUSIONS}

This preliminary study indicates that active CMV infection may occur in immunocompetent patients admitted for AHF, albeit at a low frequency and that the presence of CMV DNAemia was independently associated with a higher risk for the composite endpoint of death or readmission for AHF. Further studies are warranted in order to: 1) confirm the presence of active CMV infection in AHF, and 2) to determine whether active CMV infection plays a direct role in the progression of the disease or if it is merely an epiphenomenon linked to the severity of the inflammatory state. Should the data presented herein be confirmed, then patients displaying CMV DNAemia may constitute a subgroup of patients with AHF amenable to be managed aggressively or with specific therapeutic modalities such as immunomodulation, antiinflammatory therapies or even antiviral agents. 


\section{Acknowledgments}

This study was supported by the Ministerio de Sanidad y Consumo, Instituto de Salud Carlos III, RED HERACLES RD06/0009/1001 (Madrid, Spain).

Julio Núñez had full access to all the data in the study and takes responsibility for the integrity of the data and the accuracy of the data analysis. 


\section{References}

1 Stewart, S., MacIntyre, K., Hole, D.J., Capewell, S. and McMurray, J.J. (2001) More 'malignant' than cancer? Five-year survival following a first admission for heart failure. Eur J Heart Fail. 3, 315-22

2 von Haehling, S., Schefold, J.C., Lainscak, M., Doehner, W. and Anker, S.D. (2009) Inflammatory biomarkers in heart failure revisited: much more than innocent bystanders. Heart Fail Clin. 5, 549-60

3 Yndestad, A., Damås, J.K., Oie, E., Ueland, T., Gullestad, L. and Aukrust, P. (2006) Systemic inflammation in heart failure--the whys and wherefores. Heart Fail Rev. 11, 83-92

4 Torre-Amione, G. (2005) Immune activation in chronic heart failure. Am J Cardiol 95, 3C$8 \mathrm{C}$; discussion $38 \mathrm{C}-40 \mathrm{C}$

5 Cook, C.H., Trgovcich, J., Zimmerman, P.D., Zhang, Y. and Sedmak, D.D. (2006) Lipopolysaccharide, tumor necrosis factor alpha, or interleukin-lbeta triggers reactivation of latent cytomegalovirus in immunocompetent mice. J Virol 80, 9151-8

6 Crough, T. and Khanna, R. (2009) Immunobiology of human cytomegalovirus infection: from bench to bedside. Clin Microbiol Rev. 22, 76-98

7 Bruggeman, C.A. (2000) Does cytomegalovirus play a role in atherosclerosis? Herpes 7, $51-54$

8 Zhu, J., Shearer, G.M., Norman, J.E., Pinto, L.A., Marincola, F.M., Prasad, A., Waclawiw, M.A., Csako, G., Quyyumi, A.A. and Epstein, S.E. (2000) Host response to cytomegalovirus infection as a determinant of susceptibility to coronary artery disease: sex-based differences in inflammation and type of immune response. Circulation 102, 2491-6

9 Prösch, S., Staak, K., Stein, J., Liebenthal, C., Stamminger, T., Volk, H.D. and Krüger, D.H. (1995) Stimulation of the human cytomegalovirus IE enhancer/promoter in HL-60 cells by TNF-alpha is mediated via induction of NF-KappaB. Virology 208, 197-206.

10 Döcke, W.D., Prösch, S., Fietze, E., Kimel, V., Zuckermann, H., Klug, C., Syrbe, U., Krüger, D.H., von Baehr, R. and Volk, H.D. (1994) Cytomegalovirus reactivation and tumor necrosis factor. Lancet 343, 268-9

11 European Society of Cardiology; Heart Failure Association of the ESC (HFA); European Society of Intensive Care Medicine (ESICM), Dickstein, K., Cohen-Solal, A., Filippatos, G., McMurray, J.J., Ponikowski, P., Poole-Wilson, P.A., Strömberg, A., van Veldhuisen, D.J., Atar, D., Hoes, A.W., Keren, A., Mebazaa, A., Nieminen, M., Priori, S.G., Swedberg, K., Vahanian, A., Camm, J., De Caterina, R., Dean, V., Dickstein, K., Filippatos, G., Funck-Brentano, C., Hellemans, I., Kristensen, S.D., McGregor, K., Sechtem, U., Silber, S., Tendera, M., Widimsky, P., Zamorano, J.L., Tendera, M., Auricchio, A., Bax, J., Böhm, M., Corrà, U., della Bella, P., Elliott, P.M., Follath, F., Gheorghiade, M., Hasin, Y., Hernborg, A., Jaarsma, T., Komajda, M., Kornowski, R., Piepoli, M., Prendergast B., Tavazzi, L., Vachiery, J.L., Verheugt, F.W., Zamorano, J.L. and Zannad, F. (2008) ESC guidelines for the diagnosis and treatment of acute and chronic heart failure 2008: the Task Force for the diagnosis and treatment of acute and chronic heart failure 2008 of the European Society of Cardiology. Developed in collaboration with the Heart Failure Association of the ESC (HFA) and endorsed by the European Society of Intensive Care Medicine (ESICM). Eur J Heart Fail 10, 933-89

12 Gimeno, C., Solano, C., Latorre, J.C., Hernández-Boluda, J.C., Clari, M.A., Remigia, M.J., Furió, S., Calabuig, M., Tormo, N. and Navarro D. (2008) Quantification of DNA in plasma by an automated real-time PCR assay (CMV PCR Kit, Abbott) for surveillance of active 
cytomegalovirus infection and guidance of pre-emptive therapy for allogeneic hematopoietic stem cell transplant recipients. J Clin Microbiol 46, 3311-8

13 Royston, P. and Sauerbrei, W. (2008) Multivariable Model-building: A Pragmatic Approach to Regression Analysis Based on Fractional Polynomials for Modelling Continuous Variables. Wiley-Blackwell, Chichester, UK

14 May, S. and Hosmer, D.W. (2004) Hosmer and Lemeshow type goodness-of-fit statistics for the Cox proportional hazards model. In Advances in Survival Analysis: Handbook of Statistics (Balakrishnana, N. and Rao, C.R., eds), Vol 23. pp. 383-394. Amsterdam. Elsevier, North-Holland.

15 Fildes, J.E., Shaw, S.M., Yonan, N. and Williams, S.G. (2009) The immune system and chronic heart failure: is the heart in control? J Am Coll Cardiol 53, 1013-20

16 Miettinen, K.H., Lassus, J., Harjola, V.P., Siirilä-Waris, K., Melin, J., Punnonen, K.R., Nieminen, M.S., Laakso, M. and Peuhkurinen, K.J. (2008) Prognostic role of pro- and antiinflammatory cytokines and their polymorphisms in acute decompensated heart failure. Eur $\mathrm{J}$ Heart Fail 10, 396-403

17 Chen, D., Assad-Kottner, C., Orrego, C. and Torre-Amione, G. (2008) Cytokines and acute heart failure. Crit Care Med 36, S9-16

18 Kalil, A.C. and Florescu, D.F. (2009) Prevalence and mortality associated with cytomegalovirus infection in nonimmunosuppresed patients in the intensive care unit. Crit Care Med 37, 2350-8

19 Limaye, A.P., Kirby, K.A., Rubenfeld, G.D., Leisenring, W.M., Bulger, E.M., Neff, M.J., Gibran, N.S., Huang, M.L., Santo Hayes, T.K., Corey, L. and Boeckh, M. (2008) Cytomegalovirus reactivation in critically ill immunocompetent patients. JAMA 300, 413-22

20 Osawa, R. and Singh, N. (2009) Cytomegalovirus infection in critically ill patients: a systematic review. Crit Care 13, R68

21 Söderberg-Nauclér, C. (2006) Does cytomegalovirus play a causative role in the development of various inflammatory diseases and cancer? J Intern Med 259, 219-46

22 Varani, S., Frascaroli, G., Landini, M.P. and Söderberg-Nauclér, C. (2009) Human cytomegalovirus targets different subsets of antigen-presenting cells with pathological consequences for host immunity: implications for immunosuppression, chronic inflammation and autoimmunity. Rev Med Virol 19, 131-45

23 von Muller, L., Klemm, A., Durmus, N., Weiss, M., Suger-Wiedeck, H., Schneider, M., Hampl, W. and Mertens, T. (2007) Cellular immunity and active cytomegalovirus infection in patients with septic shock. J Infect Dis 196, 288-95

24 Vornhagen, R., Plachter, B., Hinderer, W., The, T.H., Van Zanten, J., Matter, L., Schmidt, C.A., Sonneborn, H.H. and Jahn, G. (1994) Early serodiagnosis of acute human cytomegalovirus infection by enzyme-linked immunosorbent assay using recombinant antigens. J Clin Microbiol 32, $981-86$

25 Lin, L., Kim, S.C., Wang, Y., Gupta, S., Davis, B., Simon, S.I., Torre-Amione, G. and Knowlton, A.A. (2007) HSP60 in heart failure: abnormal distribution and role in cardiac myocyte apoptosis. HSP60 in heart failure: abnormal distribution and role in cardiac myocyte apoptosis. Am J Physiol Heart Circ Physiol 293, H2238-47

26 Kim, S.C., Stice, J.P., Chen, L., Jung, J.S., Gupta, S., Wang, Y., Baumgarten, G., Trial, J. and Knowlton, A.A. (2009) Extracellular heat shock protein 60, cardiac myocytes, and apoptosis. Circ Res 105, 1186-95

27 Bason, C., Corrocher, R., Lunardi, C., Puccetti, P., Olivieri, O., Girelli, D., Navone, R., Beri, R., Millo, E., Margonato, A., Martinelli, N. and Puccetti, A. (2003) Interaction of 
antibodies against cytomegalovirus with heat-shock protein 60 in pathogenesis of atherosclerosis. Lancet 362, 1971-7 


\section{Figure legends}

Figure 1

Serum levels of cytokines stratified by CMV DNAemia

IL-1 $\beta$ : interleukin 1 beta; IL-6: interleukin 6; IL-10: interleukin 10; TNF- $\alpha$ : tumor necrosis factor alpha; TNF- $\alpha / \mathrm{IL}-10$ : tumor necrosis factor alpha/interleukin 10 ratio; IL-6/IL-10 ratio: interleukin 6/interleukin 10 ratio

Figure 2

2a Cumulative risk of all-cause mortality stratified by CMV DNAemia

$2 \mathrm{~b}$ Cumulative risk of the composite endpoint of all-cause mortality and new admission for acute heart failure stratified by CMV DNAemia

Figure 3

Cumulative risk of the composite endpoint of all-cause mortality and new admission for acute heart failure stratified by presence of CMV IgM 
Figure 1

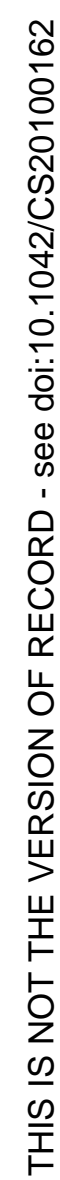

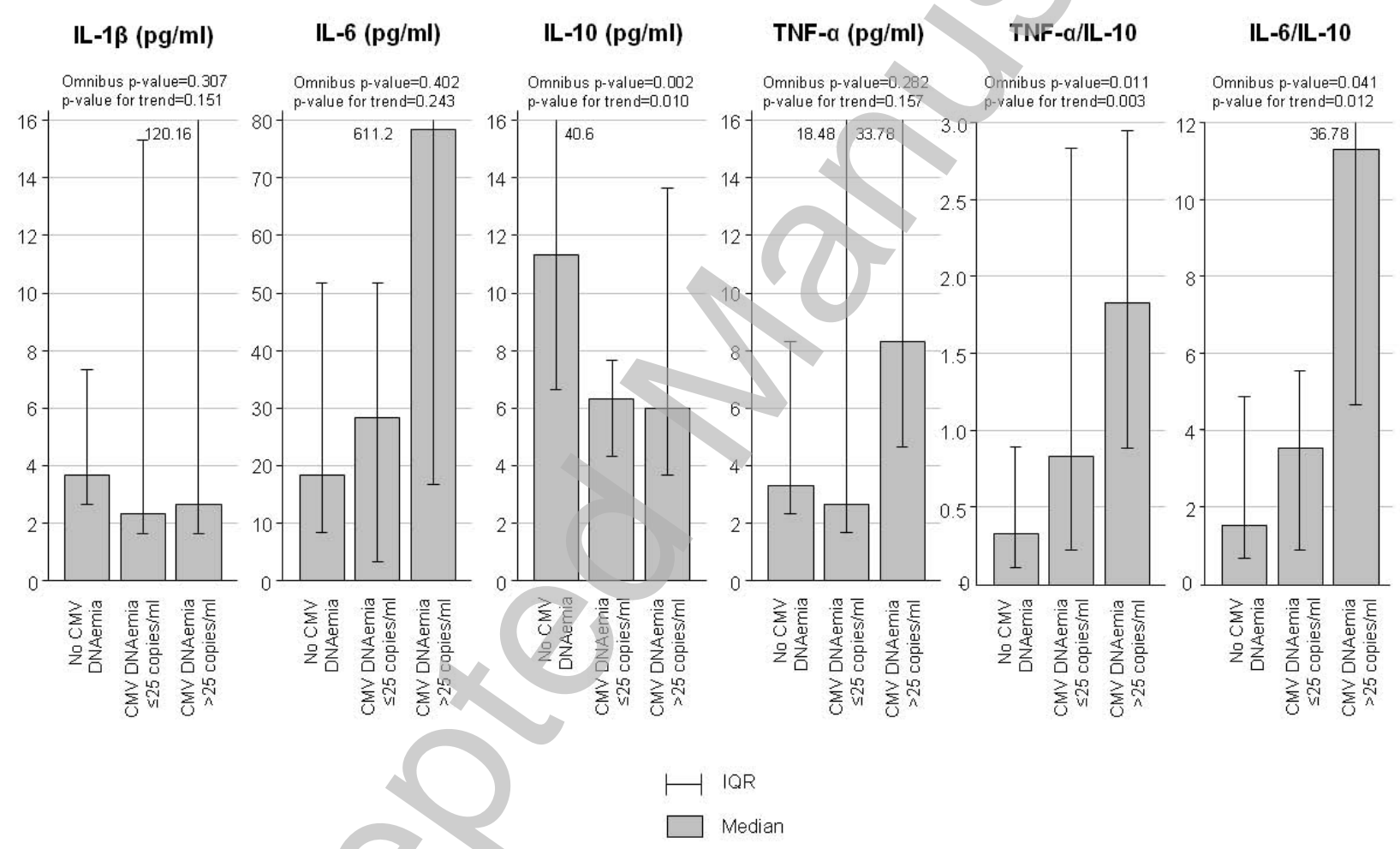




\section{Figure 2}

$2 a$

$2 b$

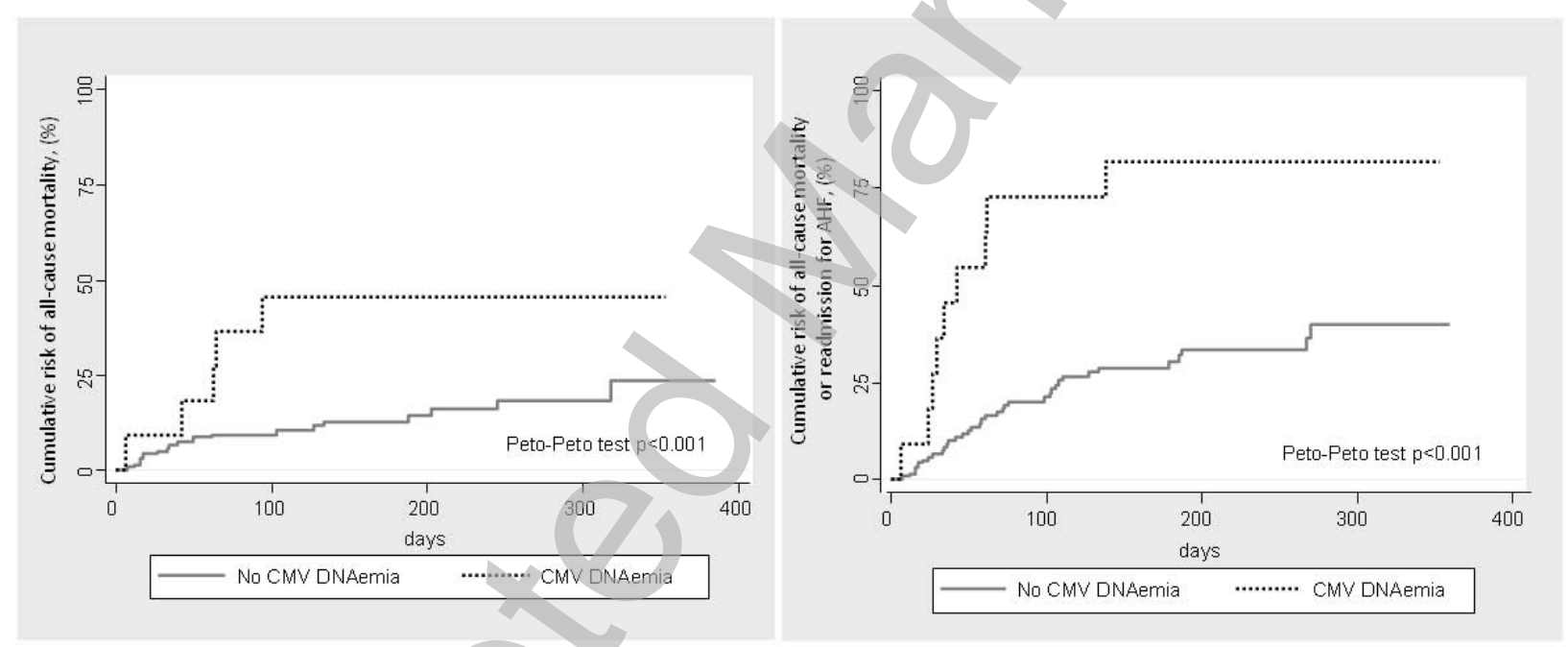




\section{Figure 3}

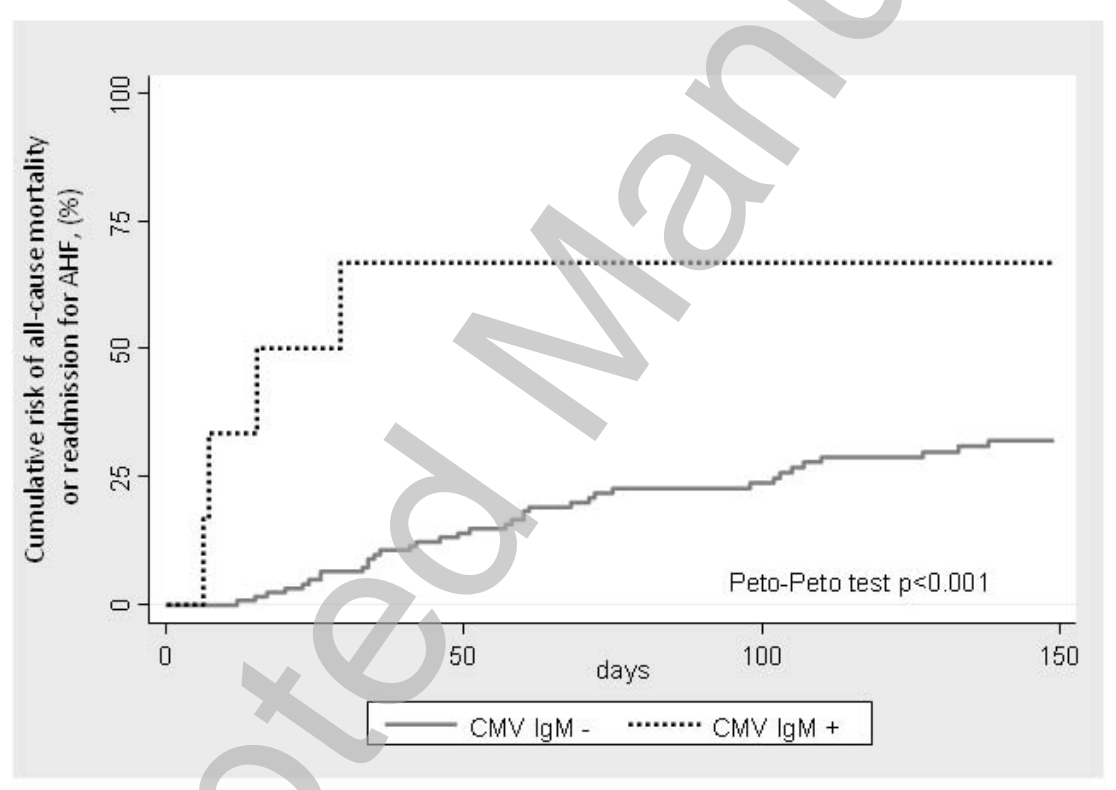


Table 1

Baseline characteristics stratified by CMV status

\begin{tabular}{|l|c|c|c|}
\hline & $\begin{array}{c}\text { CMV } \\
\text { DNAemia } \\
\mathrm{n}=11 \\
(8.3 \%)\end{array}$ & $\begin{array}{c}\text { No CMV } \\
\text { DNAemia } \\
\mathrm{n}=121 \\
(91.7 \%)\end{array}$ & p-value \\
\hline \multicolumn{3}{|c|}{ Demographic and medical history } \\
\hline Age, years & $77(54-79)$ & $76(67-81)$ & 0.705 \\
\hline Gender (male), n (\%) & $8(72.7)$ & $60(49.6)$ & 0.141 \\
\hline $\begin{array}{l}\text { Previous admission for } \\
\text { AHF, n (\%) }\end{array}$ & $7(63.6)$ & $63(52.1)$ & 0.462 \\
\hline Hypertension, n (\%) & $8(72.7)$ & $98(81)$ & 0.509 \\
\hline Dyslipidemia, $\mathrm{n}(\%)$ & $6(54.5)$ & $63(52.1)$ & 0.875 \\
\hline Current smoker, n (\%) & $1(9.1)$ & $9(7.4)$ & 0.843 \\
\hline Diabetes Mellitus, $\mathrm{n}(\%)$ & $8(72.7)$ & $57(47.1)$ & 0.104 \\
\hline $\begin{array}{l}\text { Ischemic heart disease, } \mathrm{n} \\
\text { (\%) }\end{array}$ & $7(63.6)$ & $45(37.2)$ & 0.086 \\
\hline $\begin{array}{l}\text { Valvular heart disease, } \mathrm{n} \\
(\%)\end{array}$ & $2(18.2)$ & $40(33.1)$ & 0.310 \\
\hline De novo HF & $4(36.4)$ & $51(42.1)$ & 0.709 \\
\hline ADHF, n (\%) & $9(81.8)$ & $88(72.7)$ & 0.513 \\
\hline $\begin{array}{l}\text { Acute pulmonary edema, } \mathrm{n} \\
\text { (\%) }\end{array}$ & $1(9.1)$ & $24(19.8)$ & 0.384 \\
\hline NYHA class III/IV, n (\%) & $1(9.1)$ & $15(12.4)$ & 0.748 \\
\hline COPD, n (\%) & $1(9.1)$ & $16(13.2)$ & 0.695 \\
\hline Stroke, n (\%) & $0(54.5)$ & $53(43.8)$ & 0.493 \\
\hline PAD, n (\%) & $7(63.6)$ & $77(63.6)$ & 1.000 \\
\hline $\begin{array}{l}\text { Radiological pleural } \\
\text { effusion, n (\%) }\end{array}$ & $14(11.6)$ & 0.233 \\
\hline Peripheral edema, $\mathrm{n}(\%)$ & $5.1)$ & $5(4.1)$ & 0.450 \\
\hline
\end{tabular}




\begin{tabular}{|l|c|c|c|}
\hline $\begin{array}{l}\text { Previous use of diuretics, } \mathrm{n} \\
(\%)\end{array}$ & $9(81.8)$ & $74(61.2)$ & 0.174 \\
\hline $\begin{array}{l}\text { Previous use of beta- } \\
\text { blockers, } \mathrm{n}(\%)\end{array}$ & $5(45.5)$ & $48(39.7)$ & 0.708 \\
\hline $\begin{array}{l}\text { Previous use of } \\
\text { ACEi/ARB, } \mathrm{n}(\%)\end{array}$ & $9(81.8)$ & $62(51.2)$ & 0.051 \\
\hline $\begin{array}{l}\text { Previous use of statins, } \mathrm{n} \\
(\%)\end{array}$ & $4(36.4)$ & $47(38.8)$ & 0.872 \\
\hline
\end{tabular}

Vital signs

\begin{tabular}{|c|c|c|c|}
\hline Heart rate, bpm & $90(90-100)$ & $90(70-100)$ & 0.504 \\
\hline $\begin{array}{l}\text { Systolic blood pressure, } \\
\mathrm{mmHg}\end{array}$ & $\begin{array}{c}120(107- \\
154)\end{array}$ & $\begin{array}{c}140(120- \\
180)\end{array}$ & 0.053 \\
\hline $\begin{array}{l}\text { Diastolic blood pressure, } \\
\mathrm{mmHg}\end{array}$ & $69(57-80)$ & $78(67-90)$ & 0.036 \\
\hline \multicolumn{4}{|c|}{$E C G$} \\
\hline Atrial fibrillation, $\mathrm{n}(\%)$ & $4(36.4)$ & $50(41.3)$ & 0.749 \\
\hline QRS >120 ms, n (\%) & $3(27.3)$ & $38(31.4)$ & 0.777 \\
\hline \multicolumn{4}{|c|}{ Biomarkers } \\
\hline Haemoglobin, g/dl & $\begin{array}{c}11.9(10.6- \\
12.9)\end{array}$ & $\begin{array}{c}12(11.1- \\
13.1) \\
\end{array}$ & 0.559 \\
\hline Serum creatinine, $\mathrm{mg} / \mathrm{dl}$ & $\begin{array}{c}1.33(1- \\
1.64)\end{array}$ & $\begin{array}{l}1.28(1.03- \\
1.67)\end{array}$ & 0.767 \\
\hline Uric acid, mg/dl & $7(6.3-9.6)$ & $8(6.5-9.71)$ & 0.249 \\
\hline Sodium, $\mathrm{mEq} / \mathrm{l}$ & $\begin{array}{c}140(136- \\
142)\end{array}$ & $\begin{array}{c}140(138- \\
142)\end{array}$ & 0.628 \\
\hline Troponin I, ng/ml & $0.2(0-1)$ & $0.1(0-0.3)$ & 0.186 \\
\hline NT-proBNP, pg/ml & $\begin{array}{c}7862(2040- \\
14996)\end{array}$ & $\begin{array}{c}3329(1506- \\
7612)\end{array}$ & 0.159 \\
\hline $\begin{array}{l}\text { NT-proBNP } \geq 8500 \mathrm{pg} / \mathrm{ml}, \\
\mathrm{n}(\%)^{+}\end{array}$ & $5(54.4)$ & $28(23.1)$ & 0.102 \\
\hline $\mathrm{CA} 125, \mathrm{U} / \mathrm{ml}$ & $\begin{array}{l}104(22- \\
214)\end{array}$ & $\begin{array}{l}55.5(27.7- \\
130.8)\end{array}$ & 0.294 \\
\hline $\mathrm{IL}-1 \beta, \mathrm{pg} / \mathrm{ml}$ & $\begin{array}{c}2.28(1.72- \\
15.24)\end{array}$ & $\begin{array}{l}3.63(2.51- \\
7.09)\end{array}$ & 0.124 \\
\hline IL-6, pg/ml & $\begin{array}{l}27.2(14.22- \\
141.66)\end{array}$ & $\begin{array}{l}17.8(9.41- \\
50.90)\end{array}$ & 0.390 \\
\hline $\mathrm{IL}-10, \mathrm{pg} / \mathrm{ml}$ & $6.3(4.1-7.9)$ & $\begin{array}{l}11.2(6.4- \\
40.6)\end{array}$ & 0.005 \\
\hline TNF- $\alpha, p g / m l$ & $\begin{array}{c}6.47(2.58- \\
18.48)\end{array}$ & $\begin{array}{l}3.43(2.34- \\
8.60)\end{array}$ & 0.281 \\
\hline
\end{tabular}




\begin{tabular}{|c|c|c|c|}
\hline TNF- $\alpha /$ IL-10 & $\begin{array}{c}0.83(0.39- \\
2.85)\end{array}$ & $\begin{array}{c}0.31(0.09- \\
0.78)\end{array}$ & 0.003 \\
\hline IL-6/IL-10 & $\begin{array}{c}4.96(3.29- \\
17.92)\end{array}$ & $\begin{array}{c}1.4(0.35- \\
4.88)\end{array}$ & 0.021 \\
\hline \multicolumn{4}{|c|}{ Echocardiography } \\
\hline LVEF, \% & $36(25-58)$ & $52(36-61)$ & 0.080 \\
\hline LVEF<45\%, n (\%) & $8(72.7)$ & $46(38)$ & 0.025 \\
\hline $\mathrm{LAD}, \mathrm{mm}$ & $40(37-48)$ & $42(37-49)$ & 0.873 \\
\hline LVDD, mm & $60(52-64)$ & $53(49-61)$ & 0.126 \\
\hline Septum, mm & $11(8-12)$ & $12(10-13)$ & 0.210 \\
\hline Posterior wall, mm & $11(10-12)$ & $11(9-12)$ & 0.993 \\
\hline LV mass, $g$ & $\begin{array}{c}255(209- \\
267)\end{array}$ & $\begin{array}{c}251(196- \\
299)\end{array}$ & 0.869 \\
\hline \multicolumn{4}{|c|}{ Medical treatment* } \\
\hline Beta-blockers, n (\%) & $6(54.5)$ & $76(62.8)$ & 0.589 \\
\hline Diuretics, n (\%) & $9(81.8)$ & $114(94.2)$ & 0.118 \\
\hline Spironolactone, $\mathrm{n}(\%)$ & $2(18.2)$ & $39(32.2)$ & 0.335 \\
\hline $\mathrm{ACEi}, \mathrm{n}(\%)$ & $4(36.4)$ & $47(38.8)$ & 0.872 \\
\hline $\mathrm{ARB}, \mathrm{n}(\%)$ & $2(18.2)$ & $35(28.9)$ & 0.448 \\
\hline Statins, n (\%) & $4(36.4)$ & $61(50.4)$ & 0.372 \\
\hline Oral anticoagulants, $\mathrm{n}(\%)$ & $6(54.5)$ & $53(43.8)$ & 0.493 \\
\hline Nitrates, n (\%) & $1(9.1)$ & $24(19.8)$ & 0.384 \\
\hline Digoxin, $n(\%)$ & 0 & $25(20.7)$ & 0.094 \\
\hline
\end{tabular}

CMV, cytomegalovirus; AHF: acute heart failure; ADHF: acute decompensate heart failure; NYHA, New York Heart Association; COPD; chronic pulmonary obstructive disease; $\mathrm{PAD}$, peripheral arterial disease; $\mathrm{ACEi}$, angiotensin converting enzyme inhibitor; ARB: angiotensin II receptor antagonist; NT-proBNP, N-terminal pro-brain natriuretic peptide; CA125: antigen carbohydrate 125; IL-1 $\beta$ : interleukin 1-Beta; IL-6: Interleukin 6; IL-10: Interleukin 10; TNF- $\alpha$ : tumor necrosis factor alpha; LVEF: left 
ventricular ejection fraction; LAD: left atrial diameter; LVDD: left ventricular diastolic diameter; LV mass: left ventricular mass.

Values are expressed as mean (interquartile range), categorical variables are presented as percentages.

${ }^{\S}$ Last NYHA functional class measured under clinically stable conditions.

${ }^{\dagger} \mathrm{NT}$-proBNP upper quartile.

*Treatment at discharge for them who survive to index admission and in-hospital treatment for them who died during index hospitalization. 
Table 2

Characteristics and prognosis of patients with CMV DNAemia

\begin{tabular}{|c|c|c|c|c|c|c|c|c|c|c|}
\hline \multirow[b]{2}{*}{$\begin{array}{l}\text { Patient } \\
\text { number }\end{array}$} & \multirow[b]{2}{*}{ Age } & \multirow[b]{2}{*}{ Sex } & \multirow[b]{2}{*}{ Etiology } & \multicolumn{4}{|c|}{ Clinical features } & \multirow{2}{*}{$\begin{array}{l}\text { CMV } \\
\text { DNAemia, } \\
\text { copies } / \mathrm{mL}\end{array}$} & \multirow[b]{2}{*}{$\operatorname{Ig} M$} & \multirow[b]{2}{*}{ Evolution } \\
\hline & & & & $\begin{array}{l}\text { SBP/ } \\
\text { DBP, } \\
\mathrm{mmHg}\end{array}$ & $\begin{array}{l}\text { HR, } \\
\text { bpm }\end{array}$ & $\begin{array}{l}\text { LVEF } \\
\%\end{array}$ & $\begin{array}{c}\text { NT- } \\
\text { pro } \\
\text { BNP, } \\
\text { pg/ml } \\
\end{array}$ & & & \\
\hline 1 & 77 & M & CHD & $75 / 40$ & 90 & 25 & 14996 & 72 & + & $\begin{array}{l}\text { In-hospital } \\
\text { death for HF } \\
\text { day } 6\end{array}$ \\
\hline 2 & 52 & M & $\begin{array}{l}\text { Severe } \\
\text { aortic } \\
\text { stenosis, } \\
\text { CHD }\end{array}$ & $170 / 80$ & 130 & 68 & & 10 & - & $\begin{array}{l}\text { Rehospitalizati } \\
\text { on for AHF } \\
\text { day } 24 \text {. Aortic } \\
\text { valve } \\
\text { replacement } \\
\text { and CABG } \\
\text { day } 30 \text {. Alive } \\
\text { day } 281 \\
\end{array}$ \\
\hline 3 & 83 & $\mathrm{~F}$ & $\begin{array}{l}\text { Double } \\
\text { mitral } \\
\text { severe } \\
\text { lesion }\end{array}$ & $107 / 57$ & 90 & & 2663 & 50 & - & $\begin{array}{l}\text { Readmission } \\
\text { for AHF day } \\
\text { 23. Death for } \\
\text { pneumonia } \\
\text { day } 93 .\end{array}$ \\
\hline 4 & 42 & M & CHD & $120 / 65$ & 100 & 29 & 10291 & 31 & + & $\begin{array}{l}\text { Readmission } \\
\text { for AHF day } \\
29 . \text { HF death } \\
\text { day } 64\end{array}$ \\
\hline 5 & 77 & $\mathrm{~F}$ & $\begin{array}{c}\text { CHD. } \\
\text { Aortic } \\
\text { prosthesis } \\
10 \text { years ago }\end{array}$ & $120 / 60$ & 90 & 38 & 7862 & 6 & - & $\begin{array}{l}\text { Readmissions } \\
\text { for AHF day } \\
34 \text { and } 298 . \\
\text { Alive day } 311\end{array}$ \\
\hline 6 & 79 & M & CHD & $110 / 70$ & 80 & 18 & 12410 & 36 & - & $\begin{array}{l}\text { Death for APE } \\
\text { in ED day } 42\end{array}$ \\
\hline 7 & 73 & M & & $95 / 50$ & 120 & 26 & 4437 & 7 & - & $\begin{array}{l}\text { Readmission } \\
\text { for AHF day } \\
60 . \mathrm{HF} \text { death } \\
\text { day } 62 \\
\end{array}$ \\
\hline 8 & 85 & M & HMC & $154 / 69$ & 90 & 58 & 1055 & 6 & - & $\begin{array}{l}\text { Readmission } \\
\text { for AHF days } \\
61 \text { and } 184 . \\
\text { Alive day } 284\end{array}$ \\
\hline 9 & 75 & M & CHD & $153 / 85$ & 95 & 24 & 21794 & 10 & - & $\begin{array}{l}\text { Readmissions } \\
\text { for AHF day } \\
\text { 138. Alive day } \\
327\end{array}$ \\
\hline 10 & 77 & $\mathrm{M}$ & CHD & $110 / 70$ & 65 & 41 & 35000 & 11 & - & Alive day 247 \\
\hline 11 & 54 & $\mathrm{~F}$ & CHD & $\begin{array}{c}190 / 10 \\
0 \\
\end{array}$ & 95 & 36 & 2040 & 10 & - & $\begin{array}{l}\text { CABG day } 21 . \\
\text { Alive day } 353\end{array}$ \\
\hline
\end{tabular}


CMV, cytomegalovirus; SBP, systolic blood pressure; DBP, diastolic blood pressure; LVEF, left ventricular ejection fraction; HR, heart rate; NT-proBNP, N-terminal probrain natriuretic peptide; IgM, immunoglobulin M; M, male; F, female; HF, heart failure; $\mathrm{CHD}$, coronary heart disease; $\mathrm{CABG}$, Coronary artery bypass graft surgery; HMC, hypertensive myocardiopaty. 
Table 3

Hazard ratios for the composite endpoint (all-cause mortality or readmission for acute heart failure) attributable to the presence of CMV infection

\begin{tabular}{|l|c|c|}
\hline \multicolumn{2}{|c|}{ Unadjusted } & HR $($ CI 95\%) \\
\hline \multicolumn{2}{|c|}{1} & $<0.001$ \\
\hline Detectable CMV DNAemia & $4.40(2.11-9.19)$ & \\
\hline No CMV DNAemia & $2.9(1.12-7.30)$ & 0.028 \\
CMV DNAemia $\leq 20$ copies/ml & $16.3(5.26-50.28)$ & $<0.001$ \\
CMV DNAemia $>20$ copies/ml & Adjusted* & \\
\hline \multicolumn{2}{|c|}{$4.39(2.02-9.52)$} & $<0.001$ \\
\hline Detectable CMV DNAemia & 1 & - \\
\hline No CMV DNAemia & $2.93(1.11-7.71)$ & 0.030 \\
CMV DNAemia $\leq 20$ copies/ml & $13.6(3.98-46.6)$ & $<0.001$ \\
CMV DNAemia $>20$ copies/ml & & \\
\hline
\end{tabular}

*Final multivariate Cox model adjusted by previous admission for AHF, systolic blood pressure on admission, Charlson comorbidity index, serum sodium, serum NTproBNP, and serum CA125.

CMV: cytomegalovirus; AHF: acute heart failure; NT-proBNP: NT-pro brain natriuretic peptide; CA125: antigen carbohydrate 125 